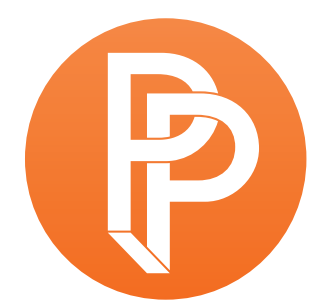

PERFORMANCE

PHILOSOPHY

\title{
UNDERSTANDING ANTI-PERFORMANCE: THE PERFORMATIVE DIVISION OF EXPERIENCE AND THE STANDPOINT OF THENON-PERFORMER
}

\section{JOSEPH GRIM FEINBERG INSTITUTE OF PHILOSOPHY, CZECH ACADEMY OF SCIENCES}

\section{Apologies to Thespis}

"I am at fault," Rousseau begins his classic complaint against the institution of the theater, "if I have on this occasion taken up my pen without necessity" (Rousseau 1968, 3). ${ }^{1}$ Is it really necessary now for me to lodge yet another complaint? Like Rousseau, I love the theater. I love the excited uncertainty that overcomes me when I sit, before the show, before the stage. Everything that has been planned-by the playwright, the director, the producers, and the actors-now could come undone. I love how the theater engages its public and its world, necessarily reacting in each moment to the audience and the institutions that surround us. I love how the theater creates an alternative world, a staged representation that reveals the faults and possibilities of the world it represents. And yet... I can't help sympathizing with those who've pointed to theater's faults.

Maybe l've sat through one mediocre play too many, or read a few too many celebratory articles on the inherently subversive, dynamic, and progressive qualities of performance, or maybe I've just spent too much time feeling ashamed among people who are much better performers than I. I can only write about performance from the position of an outsider, of someone who, of course, plays roles as much as anyone in the course of everyday life, but who has no special talent or professional qualification in the art of performing. But that is precisely why I've "taken up my pen" to write about performance. Performance, being a fundamental part of life (or at least of modern life), is too important to be written about only by those who see it, or who theorize as if they saw it, through the eyes of skilled performers. Performance should also be seen and analyzed from the 
standpoint of those who stand outside performance, observing it from the space we literally or metaphorically call "offstage."

This standpoint, the standpoint of the non-performer, might help put the standpoint of performance in perspective. If we take anti-theatrical complaints seriously (if we see them, pace Barish [1985], as something rather more than "prejudice"), we might complicate the idea that performance is inherently subversive, and we might consider how theater-or, more generally, performance, wherever it is found-is also complicit in maintaining established institutions. But a look at performance from the standpoint of the non-performer should also complicate our view of anti-theatricality. One-sidedly anti-theatrical attitudes have their limitations, after all, and resistance to the performative preservation of established institutions comes in a wide variety of forms. Rather than looking separately at theatricality and anti-theatricality, we can draw attention to the mutual interdependence of the theater and its opponents, or of performance and what I'Il call anti-performance. If we want to effectively intervene in institutions, to destabilize those that cause oppression and push forward those that promise liberation, we should try to put both performance and anti-performance in their places. If we want to better understand what performance can do-to understand how performance can intervene in the world-it will help to understand what can be done to, and against, performance.

Ultimately, however, the most significant effect of performance may not lie in performance's inherent qualities (subversive or conservative, alienating or liberating), but in the way the principle of performance divides social experience into spheres of the performed and non-performed. Once performance came to offer a framework for understanding all aspects of modern social experience (McKenzie 2001; Egginton 2003), this performative division became a constitutive principle that could shape all forms of intervention into public institutions and private life. Varying modes of intervention, drawing on a mix of performative and anti-performative elements, must navigate this performance/non-performance divide, continually bringing the non-performed into the space of performance, and bringing performative principles down off the stage, into what modern subjects have tended to call-in opposition to performed fiction-"real life." And because the notion of performance invokes an idea of the real that lies somewhere outside performance, in some place where it is imagined that people do not perform but simply "are," reflection on performance is also a reflection on ontology.

Performance theorists have long been in the habit of contrasting performance to static, immutable being. Performance, after all, evokes indeterminacy, change, making, doing, and becoming. ${ }^{2}$ But the phenomenon of anti-performance should remind us that performance is also something else. When audiences rebel against performances, when spectators rebel against their condition as mere spectators, when fans and voters bemoan the fakeness of those who appear on the public stage, what typically bothers them isn't exactly the creative whirlwind of endless becoming. They are bothered, more often, by a sense that the process of becoming has been misplaced, that only the surfaces of things are changing, while what really matters-what might most need changingremains the same. They are bothered by the sense that the performers of the world (the minions of performers who seem to have escaped the stage and filled the whole world) are only pretending 
to become what they appear to become, offering visions and identities that are nothing more than fiction. The non-performers are bothered by the sense that they weren't invited to take part in the process of becoming. This is why rebellions against performance are so often carried out in the name of authentic reality and true experience posed against false appearances. They reach out towards something that is not only performed ("played," "acted out," "made believe"), but really "is." The question of appearance makes performance appear as a problem.

The problem is a problem of division. Performance presents reality not only as fluid, but also as divided. Performance may be everywhere, revealing the mutability of all things, but it also sets boundaries between those who enact and realize this mutability and those who contemplate it from a position of distance. Even if, as Jon McKenzie puts it, "Today, it's all performance to us" (McKenzie 2001, 3)-not all of everything is performance. Performance becomes ubiquitous by cutting through all things, defining the performative and non-performative dimensions of whatever it touches. If anything-or everything-becomes performance, then in the same moment it also becomes non-performance.

I suggest that, even as we expand the notion of performance, we not lose sight of the theatrical context that gave birth to the concept. Even when we are not talking about theater per se, we are talking about something that is like theater, above all in this respect: performance implies something performed by someone to someone. Every performance demands its audience and its "outside world." When the theater became a metaphor for understanding life in general, the metaphor gave us not only the stage, but also the backstage, the audience, and the street before the theater's doors. If it is the case, as Goffman (1973) taught us, that everyone performs, then it is equally the case that everyone spectates. Everyone sometimes sits and watches, sometimes contentedly, sometimes angrily, while others perform.

Does this "problem" have a solution? I won't offer a solution that is singular and final, but l'll point to one way in which the problem might be addressed and re-framed, solved, perhaps, without being definitively re-solved: addressed not by rejecting performance or non-performance in the name of its inseparable other, but by confronting the performative division of the world, precisely at the point of division, with other notions of creative, transformative activity that cross and blur the line between the performed and non-performed.

\section{The Ambivalence of Performance}

In the 2000 preface to his Theatre of the Oppressed, Augusto Boal retells an origin myth of Western theater. One day, when Solon, the political boss of Athens, came to watch the municipal Chorus sing its dithyrambs, one of the singers stepped out of line. His name was Thespis. Though he himself was a writer and choreographer, something came over him, and he refused to sing the words and follow the movements that had been prepared. He improvised, spoke his mind, spoke what he imagined or pretended was his mind, spoke the mind of a character that he was inventing on the spot. No one on stage had ever invented a character before. No one in the audience knew what he might do, and Solon for one had an interest in knowing what the denizens of his city might 
do-and see and hear. Solon was not pleased (Boal 2008, xi-xiv). Theater was born, the story goes, when the singer set aside his lyrics to become a freestyler or, as we might say with somewhat less anachronism, to become a rhapsodist, a remixer and re-inventor of verse. The authorities wrung their hands and issued angry threats and initiated friendly coercion and did whatever they could to regulate and re-channel the creative and disruptive energy that had been unleashed and could no longer be fully contained. For those looking to subvert established institutions, in this story the performer is the hero.

Before Performance, in this story, there is Order. Order trembles when Performance enters the scene. Order trembles because Performance makes Order into a scene, where nothing is predictable, everything can be reenacted, and in the course of reenactment everything can be reimagined. A song is written, but the performance un-writes it. A play is scripted, but the performance reacts to, resists, remakes, and opens gaps in the script each time the play is performed. In the shadow of performance, mere text appears turgid. All that is stable and solid melts under the performer's mask. The performative principle reminds the planners of the world that nothing can ever be fully planned. It reminds the guardians of the world's institutions that at any moment an institution's carefully built edifice can be made into a stage, where it can be represented as a mockery of itself or can be embarrassed by being shown what it could be but has failed to become.

Nevertheless, one could tell another myth of the origins of the theater that contradicts this heroic telling on every essential point. One could tell of a Thespis who is not a subversive rebel but a representative of aristocracy. This would be a myth not of primordial rebellion but of original betrayal. In this telling, what came before the theater would not be the established Order of the elites, but the unruly disorder of popular festivals, parades, feasts, and bacchanalia, which were then given scripts and placed on the stage, where they could be observed and judged and subdued. The Chorus, here, would not represent the institutions of Order but the voice of the people, which the actor-protagonist would answer with the wisdom and hubris of the nobleman who steps before the Chorus on stage. The noble's wise actions could be held up for emulation, his tragic flaws held up for condemnation; the audience's civic virtues could be strengthened, its subversive vices purged. Thanks to theater, the established order would be maintained. The Thespis of this myth would not follow in the footsteps of Prometheus (as Boal suggested in his preface: Boal 2008, xiii). He would play the role assigned in the other myth to Zeus, who punished Prometheus for playing with fire. If there is anyone in this story who could rebel against the order of the day, it would not be the actor but the audience, whose anarchic inclinations the actor has come to redirect and restrain.

As a matter of fact, such a story has been told-by none other than Boal himself, in the very same book to which he wrote the preface discussed above. This counter-narrative appears in the book's first and fourth chapters (Boal 2008, 29, 42, 95), but elements of it appear even within the preface itself $(x-x i)$. How is it possible that these two myths are told side by side in the work of a single author who, by his own account, hardly changed his views on theater over the course of his career (ix)? 
Maybe it is possible because the second myth complements the first, even in contradicting it. Myths, after all (as Lévi-Strauss recognized: Lévi-Strauss 1969-1981), work through contradictions in the phenomena they mythologize, and the most contradictory of phenomena generate most myth. A thing without contradiction would hardly be worth mythologizing. Performance may be worth mythologizing - worth loving and fearing_precisely because it is full of contradiction.

These two origin myths of the theater reflect two different ways of writing about performance, which reflect the fundamental contradiction contained in theater. Some writers, often in a celebratory tone, emphasize the dynamic, subversive, and potentially liberating qualities of performance (Schechner [1988] offers a classic example; Butler [1990] offers another; but see also Phelan [1993] and many others; on the celebratory approach to folklore performance, see e.g. Bauman [1978]). ${ }^{3}$ Other writers (and as Boal's case shows, sometimes the same writers at other moments) emphasize the conservative, alienating, and hierarchical side of performance, the ways in which existing social institutions are "performed," with the people involved in them playing roles assigned by others or observing representations produced by others. (I have in mind not only classic opponents of the theater, like Rousseau [1968]; but also Goffman [1973]; and so many publications on "performing power," "performing the nation," "performing gender," "performing race," and so on.) One might get the impression from reading these bodies of work side by side that there exist two distinct types of performance, two easily separable sides of theatricality. Boal, for example, described two opposing types of theater, a "theater of oppression" that enforces established norms and a "theater of the oppressed" that gives spectators the power to transform those norms (Boal 2008, 135). ${ }^{4}$ Distinctions like this are no doubt important, but I question whether the phenomena they describe can be understood in isolation from one another. ${ }^{5}$ Some performances may be more oppressive than others, but can social critics really keep only the side that subverts order, without also exposing the side that conserves? Can authorities, for their part, make use only of the conservative side of performance without exposing themselves to the subversive side? Because these differing attitudes toward the theater are not typically considered together, as part of a single system, we tend to lose sight of the interrelation between them.

Maybe both rebellion and repression can be found at the origin of the theater because performance always contains both tendencies. Performance destabilizes order, but order also makes good use of performance. No performance can disrupt order unless there is first an expectation of order-what we might call a "script" that comes between institutionalized order and the moment of performing, offering structures and roles that are supposed to be performed. Every performance alters the script, but there can be no performance without some sort of script (written or unwritten) to begin with, and performance realizes and preserves the script, even while altering it, by repeatedly bringing it into the space of representation. It is worth considering the possibility that performance can undermine order and change institutions only on the condition that most of the time, in most respects, it affirms what has been already given. Every given order-whether we are speaking of a theatrical genre or a social institution-devises plans for its orderly maintenance and development. These plans call on actors to carry them out. And many people heed the call, even if it not always quite as their directors intended. ${ }^{6}$ 
It can be expedient at various moments to emphasize only one side or the other of performance, but if we are looking for a concept of performance that captures most of what people typically call performance or describe in performative terms, that concept should encompass performance's alienating as well as liberating sides, performance's role in preserving order as well as its potential for subversion. By capturing the complications and contradictions at the heart of performance, we can better understand what performative interventions-and anti-performative interventionscan accomplish.

Martin Puchner has written on how anti-theatrical attitudes not only exist outside theatrical circles, but have also become a constitutive element of modernist theater (Puchner 2002; 2013; see also Ackerman 2013, 281). But I'd like to take this insight a bit farther. Not only are anti-theatrical or anti-performative attitudes constitutive of the theater, but the tension between performance and anti-performance has also become constitutive of how we perceive the world. This becomes clearer when we look at performance from the standpoint of the non-performer. This standpoint highlights the ways in which non-performers experience performance as something separate from them, beyond their control. Performance appears to them as something that might destabilize the world they have come to count on, but also as something that they themselves might seek to destabilize, if they were ever included in the process of performing.

In order to better understand how performance appears from the standpoint of the nonperformer, I suggest we turn to the anti-theatrical tradition as a reflection (however limited) of this experience.

\section{The Spread of the Spectacle and the Performative Protection from Intervention}

In his complaint against the theater, Rousseau identified essentially the same problem that Boal would later observe: where once there had been popular festivals, now there was aristocratic spectacle. And where there still were popular festivals, there was no need for theater. A free people should refuse to let theaters be built in its midst. He wrote: "let us not adopt these exclusive entertainments which close up a small number of people in melancholy fashion in a gloomy cavern, which keep them fearful and immobile in silence and inaction [...]" (Rousseau 1968, 125). A republic should "make the spectators into the spectacle"; it should "make them actors themselves" (125). ${ }^{7}$ What was a republic, after all, but a society that was actively-and cheerfully, honorably, without pretense-made by its own people? If people's activity was its own virtue and pleasure, did they have any need to pretend to (to act as if they possessed) any virtue and pleasure that was not already theirs? Did they have any need to watch virtue and pleasure performed to them by others?

Much later, without directly referring to Rousseau, Guy Debord (1994) expanded the notion the "spectacle" beyond the theater proper. Where Rousseau emphasized the separation between actors and audiences, Debord condemned the separation of images from directly lived life. Life presents itself as spectacle, he said, because people interact through the medium of images that they can buy and sell but cannot control. Instead of interacting with one another directly, people become spectators to images that come between them. Pleasurable images are offered up for 
consumption in so many gloomy caverns. Images of virtue are presented to the public for admiration, but how often is the public invited to create its own counter-images? Put in other terms, we can understand Debord's theory of the spectacle as a theory of performance. The situation of performance, Debord tells us, at least in one of its aspects, has pervaded society. People look on vast areas of life-which they have themselves created-as if they were parts of a show put on by others. People are unable to become-or they rarely become aware of the fact that they already are-actors in the play they attend.

Established institutions are preserved by this separation between spectators and spectacle, which encourages spectators to accept uncritically the images in which the institutions around them are cloaked. The more firmly established an institution is, the more firmly will it be separated from the people who are at the receiving end of its activity. Spectators are only authorized to observe spectacles; they are not empowered to intervene. True, this is only one aspect of performance. When images of institutions are placed before the public, when images of states, nations, genders, or races are "performed," they still risk being rejected or reinterpreted by the public. (And even Debord, despite his rather bleak view of spectacularized society, proposed ways of overturning and transforming the established meanings of received images.) But as long as we only consider the contested meanings of images, we remain on one side of the more general divide between the performed and non-performed. The images that are represented in performance continually change, but who does the changing? The performers. And who are the performers? As a rule (a rule that can be selectively broken-yet only because it has first been established as a rule), the performers are not the audience.

Who, then, is the audience? In answering this question, l'd like to shift from academic and artistic critiques of theater to a type of anti-theatricality that appears in everyday discourse.

\section{The Self Liberated and the Self Preserved}

We may hear it said, once in a while, that someone has "performed well," and this might even be meant sincerely as a compliment. But we also hear that people are only play-acting and don't really mean what they say. We hear about politicians who pretend to speak from the heart but really speak for entrenched interests that have put them on the political stage. We hear about bureaucrats who only play the roles assigned to them and are unable to make their own decisions. We hear about employees who are pressured to improve their work performance ${ }^{8}$ and who are asked to put on fake smiles and to tell their customers and bosses what they want to hear. We also hear about artists who have sold out, who have failed to "keep it real" and merely fill the roles assigned to them by consumer demands or the latest fashions. All these people are confined by the roles they play.

We hear again in these statements of the separation between performance and non-performance, but here it isn't the audience that is set against the spectacle. It is real, sincere people who are set against fakers. We hear expressions of dissatisfaction with a world that is filling with actors. This phenomenon is relatively new in history. Although ancient Greeks may have criticized actual actors 
for acting (as Plato did, for example; Barish 1985, 5-37), the modern phenomenon has spread far beyond the bounds of the stage. Not only do we expect untruths (fiction) from actors in walled theaters, but we have come to suspect dissimulation from all sorts of people in all parts of life. All faces have come to appear as masks. If "All the world's a stage, / And all the men and women merely players," then how can people ever "be themselves"?

Champions of theatricality in life (e.g. Evreinoff 1927) have emphasized that it can be liberating to play roles, to step outside of ourselves and "be someone else." And perhaps there is no inherent reason why we should want to "be ourselves" rather than being others. But it matters a good deal what selves we begin with, which roles we step into, and who chooses them for us. More often than not, life assigns us roles we never asked to play. These roles serve as instructions for maintaining established social orders, and it is only at exceptional moments that we step out of those roles and into others of our own choosing. Whether we prefer to be our true selves or to escape our personal prisons, we have had to come to terms with a world in which the self is divided. And performance has set the terms of that division.

It is remarkable how closely William Egginton's (2003) history of theatricality runs parallel to Lionel Trilling's (1972) history of sincerity and insincerity. Just at the moment when theatrical metaphors began to permeate public discourse in Western Europe and, in Egginton's account, made it possible to conceptualize a public sphere as a space in which otherwise-private things could be performed to a public-audience (Egginton 2003, 145-47), people became preoccupied with whether their fellows really were who they seemed to be, or were only pretending (Trilling 1972, 1-25). The notion of a "true self," Trilling suggests, emerges as the person's answer to a world in which so many "selves" seemed to be merely performed. We have performance to thank for the true selves that may free us, but also for the false selves that confine us.

So the performative dimension of human activity has two sides, which pull in two directions but are not easy to pull apart. Performances can break through the performer-audience divide, but only because performance already presupposes the divide. Performance can reshape and repurpose established representations, but only because performance foregrounds the principle of representation over embodiment. Performances may draw our attention to embodied experience (for example, in physical theater or cutting-edge performance art), but if the event is a performance, then whatever is embodied by participating actors must also be seen from some position outside the embodying bodies. Performances bring the unexpected, but only because they first awaken expectations in their audiences (expectations drawn from generic conventions) and in their producers and sponsors (expectations based on well-vetted scripts). And when performances surprise us, as often as not this is due to a failure of performativity-a failure of performers or their directors to achieve their desired aims-rather than to performativity's success: actors may forget their lines or fail to be convincing in their roles; spectators may disobey the rules and invade the stage with their bodies or their tomatoes. Performers can push against the limits of performance from within, but sometimes the most subversive challenges to performance come from without. 
I distinguish between two different responses to the separation between performance and nonperformance. The first, what I call counter-performance, remains on the plane of performance itself, offering performative solutions to performative problems. Counter-performance can respond, in specific ways, to each of the major complaints that have been lodged against performance, which correspond to different aspects of the general social separation between performance and nonperformance.

Separation 1. Performance assigns roles, allowing or forcing people to step outside themselves (it creates a separation between the character and the self).

- Complaint: Performance traps actors in unwanted roles.

- Counter-performative response: Performance also enables actors to step out of unwanted roles and into other roles, which may be experienced by the actors as more liberating.

Separation 2. Performance sets rules for actors to follow (it creates a separation between acting and the actor).

- Complaint: Through script and generic convention, performance tells its characters what to do; their actions are not their own, but belong to their characters; and repeated performance of these actions reinforces the institutional framework that surrounds the given rules of performance.

- Counter-performative response: Performance always leaves room for interpretation (and performers, after all, are in some languages referred to as "interpreters"), challenging the actor to adjust the character's actions and fill in gaps in the script, leading to momentary transformations of all that was given before. Old, institutionalized roles can be replaced with new, changing roles (even if these too can become institutionalized upon repeated performance).

Separation 3. Performance places actors on stage (it creates a separation between the actors and the audience).

- Complaint: Performance separates the audience from the means of performative production, leaving the work of representation to expert performers.

- Counter-performative response: Performance also creates a space outside the everyday structures of society; from within this space, the actors can comment on society, criticize it, and transmit society's image back to itself (that is, to the public of spectators).

Separation 4. Performance focuses the audience's attention on the play of images (it creates a separation between the audience and the spectacle). 
- Complaint: Performance gives the audience a set of representations to contemplate passively.

- Counter-performative response: Because the audience is separated from the images placed before it, and it confronts the images as things alien to it, performers can employ Brecht's "estrangement effect," challenging the audience to critically confront the images offered. The critical audience does not disrupt the performance itself, but can later turn itself into a creator of counter-images, which can also be held up for contemplation and critique. (When this interchange is generalized, the resulting social space can be called a "public sphere.")

All this motion takes place within established structures of performance. But not all that takes place in relation to performance should be considered a part of performativity itself. In addition to the indeterminacy that plays out within performance, there is also the determinate negation of performance as such. This is what I've proposed calling anti-performance. Let's consider, now, the anti-performative response to the four performative separations listed above.

Separation 1. When performance assigns roles, separating the character from the self, and counter-performance enables actors to step out of unwanted roles, anti-performance looks for ways to place something perceived as real (e.g. the "real" person) on stage, disrupting distinctions, confusing characters and selves.

- For example: the comedian who tells stories from her own life; the rock musician who doesn't give a shit about society; talk shows where actors appear as "themselves"; documentary filmmaking and reality TV, where the presence of the real is central to the genre's appeal.

Separation 2. When performance sets rules, separating the acting from the actor, and counterperformance leads actors to reinterpret those roles, anti-performance pushes for actors to stop acting like actors at all. The actors toss away their scripts and speak in "their own" words.

- For example: the singer who writes her own songs; the improviser who mixes performativity with anti-performativity (as the virtuosity of the great performer confronts the freedom of the non-performer who seems to do what he wants for his own pleasure, beyond rules set by others).

Separation 3. When performance places actors on stage, separating them from the audience, and when counter-performance uses the stage for criticizing society, anti-performance brings the actors down off the stage with the aim of expanding participation.

- For example: the folk musician who gets us to sing along as if we were in her living room; street theater, where theater dispenses with the stage and enters something perceived as real life; participatory theater, where spectators' actions become a part of the performed 
work (as in Boal's theater of the oppressed); the participants in a festival, who do the aesthetic work themselves, without clear boundaries between performers and spectators.

Separation 4. When performance focuses attention on representations, setting them apart from the audience as spectacle, and when counter-performance encourages the audience to critically reflect on those images, anti-performance responds by actively opposing the images, turning attention away from them and toward the audience's own embodied actions.

- For example: audiences throwing tomatoes at the stage; non-staged dance, where there is no spectacle to observe, but there is motion to feel.

Counter-performance and anti-performance rarely appear in pure form. Because antiperformance is a reaction to performance, it appears most intensely within and around the boundaries of performance, whenever performativity appears to the public as a problem. But whereas counter-performance employs principles inherent to performativity, anti-performance involves pushing against the performative principles that have been associated with the alienating separations of modern society. Anti-performance asserts embodiment when people experience life in society as something disembodied. Anti-performance asserts participation when people feel excluded. Anti-performance asserts freedom when people experience the domination of roles and rules. Anti-performance asserts truth, authenticity, and reality when the world appears to people as mendacious and fake. There may be times when anti-performance is unneeded, when people have no sense of alienation. Anti-performance only becomes effective when performance has become a framework for understanding alienated experience. It is then that anti-performance offers a sense of reconnecting with the real. Whereas counter-performance asserts becoming against established forms of being (new, dynamic performances against old, hackneyed shows), anti-performance asserts being against the whirlwind of becoming that sweeps by and seems to leave the audience behind.

\section{The Ontology of Anti-performance}

So anti-performance, as an attempt to reach beyond performed representations and reconnect with the real, amounts to a demand for true, essential being against false appearances. The notion of being is older than the notion of performance, but a brief history of being suggests that the notion's discursive prominence is related to the rise of theatricality as a way of seeing the world. If the "history of being" (pace Heidegger, e.g. 2014) does not take for granted the existence of being, but sees the notion of being as a result of historically situated thoughts and desires (in other words, if we stop looking for "Being itself" and look instead for how beings create the idea that there can be such a thing as "being," and if we ask how it ever occurred to anyone to wonder whether anything "is" "itself"), one can trace the emergence of the notion of being in time, and one can relate the changing structure of being to shifting frameworks for understanding the world.

At moments when the social structures of early civilizations were disrupted by colonization and trade, most notably in the Greek-speaking Mediterranean and in South Asia, intellectuals began to 
inquire into the difference between reality and falsehood, essence and appearance, truth and opinion. But they did not generally see falsehood, appearance, and opinion as kinds of play-acting and subterfuge. Although Plato condemned actors for presenting a mere imitation of reality instead of reality itself, his preferred metaphor for untruth was a sort of theater without actors, his famous shadows on the wall of a cave. The shadows that people mistake for reality were, for Plato, a superficial appearance that has no performer. They were false, but they could not be liars. They were disorienting, but they could not be insincere. It was not a problem for Plato that shadows resembled performance; it was a problem that performance-or in his terms, poetic mimesisresembled shadows.

In the Mediterranean tradition and its later Western reinterpretation, ${ }^{9}$ Christian metaphysics added an additional normative layer to these distinctions, associating being with God and associating appearance with lowly, worldly life. But it was still later, when the world "became a stage," that being came to be understood as that which exists behind the scenes. Within the theatrical framework, the notion of being could be opposed to the fantastical or false world of the performed. ${ }^{10}$ And if "all the world" is a stage, then the area backstage would seem to belong to another world. Being was no longer directly accessible through philosophical speculation or devotion to God; it would be re-imagined in the form of inaccessible things-in-themselves, hidden from view the way the backstage workings of the theater are hidden from the audience. Repeated waves of modern European philosophy have offered renewed attempts to address the inaccessibility of being, either by renouncing all hope in metaphysical transcendence and placing all human existence in the realm of phenomenal appearances, or by re-defining being and appearance such that the one is included within the other. ${ }^{11}$

But the play of performance and anti-performance suggests that the choice between accessing and renouncing being need not be posed so starkly. The practices of anti-performance are techniques for reaching into being-but they can be effective only when performance has first created being by pulling curtains through experience, dividing the lived world into spaces of performance and non-performance. When the curtains are drawn and the backstage workings are revealed, when actors drop all pretense and speak as themselves, when the walls of the theater are taken down and the performers descend from the stage, the audience tastes being itself. There is no other being to be had, because being becomes being when it is separated from appearance. There is being because there is appearance. There is true reality because there is fictive performance. Each generates its opposite, and each transforms its other, as the process of reaching and concealing and subverting and affirming reality moves forward. Performed appearances help cover established institutions in a cloak of aesthetic appeal and passive approval, but when audiences become critical of performance and begin to demand authentic being in the form of really embodied participation, they also demand change in the reality that existing performative roles and representations affirm. The demand for reaching into being can become a demand for being to become something else.

It is likely that anti-performative access to being will always be short-lived. When the curtains that divide experience are drawn back, the basis of being's existence disappears. And if being is still 
pursued doggedly even after its basis has been removed, it becomes reified, fixed as immutable essence. Instead of transcending phenomenal appearance, it surrounds existence with impassable walls. The reification of being halts the dynamics of performance and anti-performance. It obstructs the free formation of representations that might rise above established reality. It forbids the playing of roles that might liberate people or things from their supposedly fixed natures. It stops the self-estrangement that can also become an emancipatory self-overcoming. (In other words, it becomes precisely what Butler pushed against with her anti-essentialist theory of performance; Butler 1990.) As long as experience is divided into performed appearances and unperformed reality, this division is not changed by attachment to one side or the other of the divide. Yet there may be some kinds of activity that do not presuppose this division of experience, and may even push against it. These kinds of activity-which need not be so short-lived-do not so much reach into an essence that is opposed to appearance, but make the search for being unnecessary in the first place.

The one-sided pursuit of anti-performance would get us no farther than the one-sided championing of performativity. Rather, the critical power of anti-performance may come precisely from its relativity. Each performance demands its own anti-performance; each anti-performance responds to a specific performative form. Each performative form creates its own form of audience that is left off the stage. After one regime of performance-one way of organizing the performative and anti-performative dimensions of reality-there comes another, and with it the line between actors and spectators shifts. New actors are given performative powers-they can adopt new roles, alter the rules of performance, change representations and redraw the boundaries of spectacle. But as long as there is a stage, there is an audience that is excluded from the stage. This audience wields its own power. Because it is placed outside the space of appearances, it resides in what the performance regime has created as real "reality." If the audience fixes its gaze on the play that unfolds before it on stage, it sees only performed appearances, while reality appears to it as inaccessible, hidden somewhere behind the backdrop and the curtains. But when the audience looks back on itself, it has the power to bring reality-its own reality-back into play.

\section{The Politics of Performance and the Anti-Politics of Anti-Performance}

Hannah Arendt may have had something slightly different in mind when she argued that politics takes place in the space of "appearance" (Arendt 1958), but her notion of "appearance" derived from a distinction between public and private space that maps closely onto my distinction between performance and non-performance. What is available for political transformation is what appears for the public to see, and political theater can change what the public sees. The theater of those like Boal goes a step further, opening up the space of appearance to new material, new participants. By breaking down the walls of the public stage, participatory theater integrates parts of reality that had been kept off the stage, pulling realities out of the metaphysics of eternal essence and placing them in the sphere of mutable appearance. But then this material becomes subject to the rules of performance, and eventually the time comes for a new round of antiperformance to be brought against it, criticizing what appears on the public stage for having 
become distant from the rest of reality. Intervention of one kind calls for intervention of another. Anti-performance, in this process, pushes performance to continual renewal.

But this kind of engagement, as I've described it, still works within a framework in which the space of political transformation is the space of appearance. What becomes political must invade the stage. What if we took things the other way around? What if, in addition to making new parts of reality changeable by bringing them into performance, we also brought performed things into the sphere of (non-performed) reality? Can politics be made to reach beyond the theatrical? Can we transform the institutions of our largely unnoticed, everyday lives? Can there be a kind of transformative activity that possesses the dynamism of performance but is not fixed to a (literal or metaphorical) stage? A kind of activity that confines itself neither to the stage nor the seats, but regularly crosses all such boundaries, disrupting the very distinction between performance and non-performance? If, as I've been suggesting, the specificity of performance is best characterized by the principle of separation (rather than by becoming or transgression), and if performance and non-performance are mutually constitutive features of this experience, is it possible to look beyond the performative divide?

Czech philosopher Karel Kosík offered one possibility in a 1966 essay titled "The Individual and History": whereas Schelling had treated history as a "play," in which players acted out a script written in advance, Kosík argued that Marx treated history as "real play and a play of reality," the outcome of which could never be fully determined beforehand (Kosík 1995, 128-29; see also Tava forthcoming). "Play," in Kosík's terms, appears as the antidote to theater. But even if scripted plays always also contain an element of indeterminacy, the notion of "real play" brings a different element to the fore. When people play at making history, they are not making something fictive that they distinguish from the real. They play roles and reverse roles and join in games and leave them to join other games. Sometimes they make their own, new games. Their play is the reality of history, even when they never step onto the political stage and never come into public view. People make history both on stage and in the offstage spaces of everyday life. In the theatrically divided world, their activity reaches into being without ceasing to become. It does not play at being (being something other than what it is), but it plays with being, explores being, becoming something new. And so the politics of the space of performance is met with an anti-politics of spaces beyond performance. The audience ceases, at least for this moment and in this aspect, to be an audience. It turns away from the stage and intervenes in all the spaces of reality that politics rarely sees. 
1 The research that went into this article was conducted under the auspices of Czech Science Foundation grant no. 17-23955S, "Unity and Multiplicity in Contemporary Thought."

${ }^{2}$ Grant, McNeilly, and Veerapen (2015) offer one of the more recent sustained explorations of this dynamic and creative temporality.

3 Phelan writes, for example, that "Performance clogs the smooth machinery of reproductive representation necessary to the circulation of capital" (Phelan 1993, 148). Does it really, though? Even leaving capitalism aside for a moment, doesn't performance play a rather fundamental role within the process of representation in the modern public sphere? Doesn't representation happen precisely when someone takes material out of an isolated context and presents it-performs it_as a set of images to be contemplated by some audience on some kind of public stage?

${ }^{4}$ McKenzie identifies more than just two types of performance, but his description implies a similar dichotomy; "within Performance Studies, [...] performance has become defined as a "liminal" process, a reflexive transgression of social structures," (McKenzie 2001, 8), while in fields like management and technology the notion of "performance" is deployed as a means of measuring efficiency or effectiveness within established structureswhich suggests, I would add (pace Phelan 1993), that performance can grease the wheels of capital circulation as much as it "clogs" them.

5 On this point I follow McKenzie (2001), who proposes a "general theory" to account for all uses of performance. But while he takes careful account of how performance shapes structures of power and knowledge, he pays less attention to what I see as most central: the separation between performance and non-performance.

${ }^{6}$ We might recall here Gustav Landauer's observation that "The state is a social relationship; a certain way of people relating to one another. It can be destroyed by creating new social relationships" (Landauer 2010, 214), or John Holloway's claim that "we are creating our own destruction" by reproducing the structures of our society (Holloway 2005, 46). In other terms, we could say that institutions continue to exist as long as they continue to be performed. See also Shannon Jackson's work on how performance studies themselves have become institutionalized and, in the process, have performed their own institutionalization (Jackson 2004).

7 Here I've revised Alan Bloom's translation. The original reads, "donnez les spectateurs en spectacle; rendez-les acteurs eux-mêmes" (Rousseau 1967, 234).

${ }^{8}$ Who are told, as McKenzie puts it, to "perform—or else" (McKenzie 2001).

9 Perhaps further research will reveal parallel developments in, for example, South Asian or Chinese philosophy, where there was a great deal of contemporaneous reflection on ontology and theater. Such research might also uncover valuable alternatives to the performance/anti-performance dichotomy that has dominated theatrical thinking in the West.

10 Axel Hutter (2017) offers a noteworthy corollary to this line of reasoning, observing that modern humans tend to attribute "meaning" to a purely human realm, while "reality" is understood to be objectively meaningless. Meaning, removed from being, is confined to a realm of fiction, narration, and theater.

${ }^{11}$ Grant, McKneilly, and Wagner (2019) have recently brought this line of thought into discussions of performance studies.

\section{Works Cited}

Ackerman, Alan. 2013. "Introduction: Modernism and Anti-Theatricality." Modern Drama 44 (3): 175-83. https://doi.org/10.3138/md.44.3.275

Arendt, Hannah. 1958. The Human Condition. Chicago: University of Chicago Press. 
Barish, Jonas A. 1985. The Antitheatrical Prejudice. Berkeley: University of California Press.

Bauman, Richard. 1978. Verbal Art as Performance. Rowley, MA: Newbury House.

Boal, Augusto. 2008. Theater of the Oppressed. Translated by Charles A. McBride, Maria-Odilia Leal McBride, and Emily Fryer. London: Pluto.

Butler, Judith. 1990. Gender Trouble: Feminism and the Subversion of Identity. London: Routledge.

Debord, Guy. 1994. The Society of the Spectacle. Translated by Donald Nicholson-Smith. New York: Zone Books.

Egginton, William. 2003. How the World Became a Stage: Presence, Theatricality, and the Question of Modernity. Albany: SUNY Press.

Evreinoff, Nicolas. 1927. The Theatre in Life. Translated by Alexander I. Nazaroff. New York: Brentano's.

Goffman, Erving. 1973. The Presentation of Self in Everyday Life. Woodstock, NY: The Overlook Press.

Grant, Stuart, Jodie McNeilly, and Maeva Veerapen, eds. 2015. Performance and Temporalisation: Time Happens. Basingstoke: Palgrave Macmillan. https://doi.org/10.1057/9781137410276

Grant, Stuart, Jodie McNeilly, and Matthew Wagner, eds. 2019. Performance Phenomenology: To The Thing Itself. Basingstoke: Palgrave Macmillan. https://doi.org/10.1007/978-3-319-98059-1

Heidegger, Martin. 2014. Introduction to Metaphysics. Translated by Gregory Fried and Richard Polt. New Haven: Yale University Press.

Holloway, John. 2005. Change the World Without Taking Power: The Meaning of Revolution Today. 2nd edition. London and Ann Arbor, MI: Pluto Press.

Hutter, Axel. 2017. Narrative Ontologie. Tübingen: Mohr Siebeck. https://doi.org/10.1628/978-3-16-155520-6

Jackson, Shannon. 2004. Professing Performance: Theatre in the Academy from Philology to Performativity. Cambridge: Cambridge University Press. https://doi.org/10.1017/CBO9780511554247

Kosík, Karel. 1995. "The Individual and History." In The Crisis of Modernity: Essays and Observations from the 1968 Era, edited by James H. Satterwhite, 123-34. Lanham, MD: Rowman \& Littlefield.

Landauer, Gustav. 2010. Revolution and Other Political Writings. Translated by Gabriel Kuhn. Oakland, CA: PM Press.

Lévi-Strauss, Claude. 1969. Mythologiques. 4 vols. Translated by John and Doreen Weightman. Chicago: University of Chicago Press.

McKenzie, Jon. 2001. Perform or Else: From Discipline to Performance. London and New York: Routledge. https://doi.org/10.4324/9780203420058

Phelan, Peggy. 1993. Unmarked: The Politics of Performance. London: Routledge.

Puchner, Martin. 2002. Stage Fright: Modernism, Anti-Theatricality, and Drama. Baltimore: Johns Hopkins University Press.

___. 2013. "Modernism and Anti-Theatricality: An Afterword." Modern Drama 44 (3): 355-61. https://doi.org/10.3138/md.44.3.355

Rousseau, Jean-Jacques. 1967. Lettre à D’Alembert Sur Les Spectacles. Paris: Garnier-Flammarion.

1968. Politics and the Arts: Letter to D'Alembert on the Theater. Translated by Alan Bloom. Ithaca, NY: Cornell University Press.

Schechner, Richard. 1988. Performance Theory. London: Routledge.

Tava, Francesco. forthcoming. "Praxis in Progress: On the Transformations of Kosík's Thought." In Karel Kosík and Dialectics of the Concrete. Edited by Joseph Grim Feinberg, Ivan Landa, and Jan Mervart. Leiden: Brill.

Trilling, Lionel. 1972. Sincerity and Authenticity. Cambridge, MA: Harvard University Press. 
Joseph Grim Feinberg received his PhD in anthropology from the University of Chicago in 2014, and he is currently a research fellow at the Philosophy Institute of the Czech Academy of Sciences. His research addresses the politics of performativity, the history of critical social thought in East-Central Europe, the problem of citizenship and exclusion, and the notion of internationalism. His book The Paradox of Authenticity, on performance and the reconceptualization of "the people" in post-Communist Slovak folklore, was released in 2018. He is also editor of Contradictions: A Journal for Critical Thought, based in Prague.

\section{(c) 2020 Joseph Grim Feinberg}

cc) (i) (2) Except where otherwise noted, this work is licensed under a Creative Commons Attribution-

(cc) BY NC $_{\text {SA }}$ NonCommercial-ShareAlike 4.0 International License. 